\title{
Unique Public Duties of CARe: JUdiCIAL ACTIVISM IN THE SUPREME COURT OF CANADA
}

\author{
BRUCE FELDTHUSEN ${ }^{*}$
}

Typically, government liability in tort depends on whether the government in question, through legislation, has consented to be held liable for its otherwise tortious acts. However, the Supreme Court of Canada has behaved in an activist manner by ignoring or eviscerating this legislation, altering and expanding what governments can be held liable for. This article explains how this process has occurred, providing five specific examples where unique public duties of care were created. An open discussion is needed about whether the Supreme Court ought to continue doing this and, if so, on what basis. This article starts that discussion.

\section{TABLE OF CONTENTS}

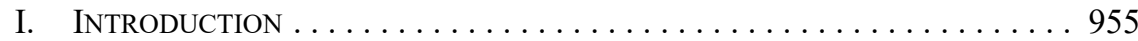

II. The UniQue Public DutIES of CARE $\ldots \ldots \ldots \ldots \ldots \ldots \ldots \ldots \ldots 958$

A. A Unique Public Duty on the Part of Police OfFicers TO ENSURE THE SAFETY OF MOTORISTS

After a Highway TRAFFiC ACCIDENT . . . . . . . . . . . . . 958

B. A UniQue Public Duty OWed by Municipalities

WHO UNDERTAKE A PROGRAM OF HOUSING INSPECTION

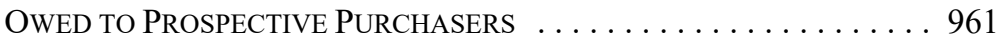

C. A Unique Public Duty on the Part of Governmental

AUTHORITIES WHO HAVE UNDERTAKEN A POLICY OF ROAD

MAINTENANCE TO EXECUTE THE MAINTENANCE IN A

NON-NEgLigent MANNER . ...................... 966

D. A Duty of Care on the Part of the Chief of Police

TO ENSURE THAT POLICE OfFicers COOPERATE WITH

AN SIU INVESTIGATION . . . . . . . . . . . . . . . . . . 969

E. A DUTY ON THE PART OF GOVERNMENT SAFETY INSPECTORS

to Protect Workers From the CONSEQUENCES OF

CRiminal Conduct Perpetrated By Others _ . . . . . . . . . . . . 973

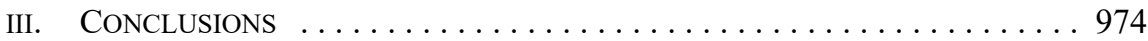

\section{INTRODUCTION}

In 2015 the Supreme Court of the United Kingdom decided Michael v. Chief Constable of South Wales Police, ${ }^{1}$ a decision described as "arguably the third most important case after Donoghue v Stevenson (1932) and Hedley Byrne v Heller \& Partners (1964) — on the

Bruce Feldthusen, BA (Queen's), LLB (Western), LLM, SJD (Michigan) is a Professor of Law at the University of Ottawa where he also served as dean from 2000-2013. He is best known for his book Economic Negligence, now in its 6th edition, and for co-authoring The Law of Torts with retired Justice Allen Linden. He has published numerous articles, particularly about tort damages including punitive damages, tort actions for sexual battery, and the tort liability of public authorities. He is Canada's representative to the World Tort Law Society.

1 [2015] UKSC 2, [2015] AC 1732 [Michael]. For the purposes of this article, the key passage of the decision is found at paras $97-100$. 
English law of negligence to be decided by the UK's highest court."'2 The Michael decision is also yet another important negligence decision rendered in the past 40 years in which the highest court in England has taken a strikingly different position than the Supreme Court of Canada. $^{3}$

Michael dealt with an action brought on behalf of a domestic violence murder victim where the police were alleged to be negligently slow in responding to her emergency telephone call seeking help. The Court held that public authorities were subject only to the same rules of negligence law as were private parties. They were not subject to unique public duties, unique in the sense that the law does not recognize the same or a fairly analogous ${ }^{4}$ duty of care on the part of private party defendants. The general rule in private party negligence law is that there is no duty to protect another by preventing harm caused by a third party. There are two exceptions: (1) when the plaintiff enjoys a position of control over the third party; and (2) when the plaintiff assumes a responsibility to protect the plaintiff under the Hedley Byrne principle. Neither of these exceptions applied in Michael.

In contrast, this article exposes five important negligence decisions of the Supreme Court of Canada in which the Court has created a unique public duty of care in negligence. Ideally, this article would also answer whether unique public duties of care are constitutionally permissible or desirable, and if so, what factors ought to guide the courts in recognizing them. Unfortunately, the best that can be accomplished at this stage is to attempt to start the

$2 \quad$ Nicholas McBride, "Michael v ChiefConstable of South Wales Police" (2015) University of Cambridge Faculty of Law Legal Studies Research Paper Series Working Paper No 21/2015, online: <ssrn.com/ abstract $=2565068>$. See also Gorringe $v$ Calderdale Metropolitan Borough Council, [2004] UKHL 15, [2004] 2 All ER 326; Furnell v Flaherty (trading as Godstone Farm), [2013] EWHC 377, [2013] PTSR D20 (QBD).

3 This is not to say that the Supreme Court of Canada would reach a different decision on the facts in Michael, but only that the Supreme Court does create unique public duties of care. As for other deviations from English law, Canada follows the two-step test for recognizing a new duty of care established in Anns v Merton London Borough Council (1977), [1978] AC 728 (HL (Eng)) [Anns], whereas the UK uses the approach illustrated in Caparo Industries Plc v Dickman, [1990] 2 AC 605 (HL (Eng)). Neither a non-privity builder nor a public authority is liable to the owner for structural damage to a building in England, whereas the owner may recover for dangerous defects in Canada: Winnipeg Condominum Corporation No 36 v Bird Construction Co, [1995] 1 SCR 85 [Winnipeg Condominium]. The duty in misrepresentation is also defined quite differently: see Bruce Feldthusen, "Hedley Byrne: Misused, then Exiled by the Supreme Court of Canada" in Kit Barker, Ross Grantham \& Warren Swain, eds, The Law of Misstatements: 50 years on from Hedley Byrne v Heller (Oxford: Hart, 2015) 261 [Feldthusen, "Hedley Byrne"].

A good example of a meaningfully analogous duty of care is Hill v Hamilton-Wentworth Regional Police Services Board, 2007 SCC 41, [2007] 3 SCR 129 [Hill]. The Supreme Court held that an investigating police officer owes a duty of care to a suspect. The Court treated it as a unique public duty. However, the decision correctly turns on the special relationship between the parties, as do many duties in private party negligence law. Hill concerns a power-dependent relationship of control and vulnerability. There is precedent for such an approach by analogy: see KLB v British Columbia, 2003 SCC 51, [2003] 2 SCR 403 [KLB] (special relationship between parent and child is analogous to the relationship between the Crown and foster children in its care). There are numerous cases that have recognized a duty of care on the part of correctional officers to protect prisoners in their custody: see Donald J Rennie et al in The 2014 Annotated Crown Liability and Proceedings Act (Toronto, Ont: Carswell, 2013) at 50-52. See also Young v Bella, 2006 SCC 3, [2006] 1 SCR 108. 
conversation. ${ }^{5}$ There is no existing foundation of governmental, judicial, or academic analyses of these important questions upon which to base meaningful conclusions. ${ }^{6}$

By "judicial activism" I mean only that the Supreme Court has imposed several unique obligations on governments and other statutory public authorities. On its own initiative, the Supreme Court has changed the balance of power between government and the courts. This has nothing to do with the term "judicial activism" as it is ideologically used to criticize judicial decisions that rely on the Canadian Charter of Rights and Freedoms ${ }^{7}$ to strike down government legislation. The word "activism" is not meant to be taken in any pejorative sense.

Nor is this article concerned primarily with the Court's use of policy in shaping negligence law. My arguments do not rely on the proposition that judges should never rely on policy when making law. ${ }^{8}$ Rather, I believe that judges should exercise restraint when making policy determinations, especially given the institutional limitations of the judicial role. Judges should make their policy decisions transparently. The main critique of the Supreme Court's role in creating unique public duties of care is that it has failed entirely to meet the transparency requirement.

I will not discuss a number of generally accepted areas of tort law that are uniquely public. David J Mullan has identified five. ${ }^{9}$ First is the tort of misfeasance in public office. This is an intentional tort, not an action in negligence. ${ }^{10}$ The defendant must knowingly exceed jurisdiction to be held liable. This action is older than the Crown liability statutes. Second, there are the constitutional "torts." These are not created by the judiciary. Damages are

See Norman Siebrasse, "Liability of Public Authorities and Duties of Affirmative Action" (2007) 57 UNBLJ 84 (his excellent treatment of unique public duties identified the same goal). See also Bruce Feldthusen, "Simplifying Canadian Negligence Actions Against Public Authorities - Or Maybe Not" (2012) 20:3 Tort L Rev 176; Paradis Honey Ltd v Canada (Minister of Agriculture and Agri-food), 2015 FCA 89, 382 DLR (4th) 720 at paras 119-46 (here, Justice Stratas calls for the development of unique sets of principles governing the liability of statutory public authorities including the right to award damages in an action for judicial review "when a public authority acts unacceptably or indefensibly in the administrative law sense and when, as a matter of discretion, a remedy should be granted" at para 132). The debate has begun in the UK: see e.g. Donal Nolan, "The Liability of Public Authorities for Failing to Confer Benefits" (2011) 127:2 Law Q Rev 260.

The Supreme Court never discusses this subject. Governments are apparently indifferent. It appears that Siebrasse, ibid and Feldthusen, ibid, are the only two to have published Canadian law review articles on point. Despite an otherwise excellent treatment of the subject, Siebrasse merely mentions the Crown liability statutes, but does not explore their impotence. See also Patrick Orr, "Speaker's Corner: Who then in law is a public servant's neighbour?," Law Times (23 February 2009), online: <www.lawtimes news.com>. The authors of the leading text, Peter W Hogg, Patrick J Monahan \& Wade K Wright, Liability Of The Crown, 4th ed (Toronto, Ont: Carswell, 2011) are well aware of the development of unique public duties of care and the neutering of the Crown Liability legislation by the courts. However, they simply accept this and do not engage in critical debate. Rennie, supra note 4 does not deal with unique public duties at all.

Part I of the Constitution Act, 1982, being Schedule B to the Canada Act 1982 (UK), 1982, c 11. See Lewis N Klar, "Judicial Activism in Private Law" (2001) 80:1/2 Can Bar Rev 215 [Klar, "Judicial Activism"]. See also Russell Brown, Judicial Activism in the Law of Negligence (JSD Thesis, University of Toronto Faculty of Law, 2006) [unpublished]; Ernest J Weinrib, "The Disintegration of Duty" (2006) 31:2 Adv Q 212; Allan Beever, Rediscovering the Law of Negligence (Oxford: Hart Publishing, 2007). Hogg, Monahan \& Wright, supra note 6 at 219, n 321; David J Mullan, "The Law of Canada" in John Bell \& Anthony W Bradley, eds, Government Liability: A Comparative Study, United Kingdom Comparative Law Series, Vol 13 (London: United Kingdom National Committee of Comparative Law, 1991) 59 .

10 Mullan, ibid at 68. Oddly, misfeasance in public office is identified as one of the established duties of care in Cooper v Hobart, 2001 SCC 79, [2001] 3 SCR 537 at para 36 [Cooper]. Perhaps the Court meant to refer instead to the liability of the chief of police recognized in Odhavji Estate $v$ Woodhouse, 2003 SCC 69, [2003] 3 SCR 263[Odhavji]. 
awarded for breach of the Constitution. ${ }^{11}$ Third is the defence of statutory authority. This is usually invoked in nuisance actions. Fourth is policy immunity. ${ }^{12}$ Finally there are residual statutory immunities. These are simply open exercises of parliamentary supremacy.

In the next section I will present five different examples of unique public duties of care. None involve direct acts that inflict compensable harm. ${ }^{13}$ Rather, these examples involve affirmative duties to protect the plaintiff from harm, often harm inflicted by a third party. The courts speak of omissions, the failure to provide public benefits, the failure to rescue, the failure to warn, and so on. ${ }^{14}$ They are:

1. A duty owed by police officers to take reasonable care to ensure the safety of motorists after a highway traffic accident. ${ }^{15}$

2. A duty owed by municipal governments that have undertaken a policy of housing inspection, owed to prospective purchasers of real estate. ${ }^{16}$

3. A duty on the part of governmental authorities who have undertaken a policy of road maintenance, owed to highway users. ${ }^{17}$

4. A duty owed by the chief of police to use reasonable care to ensure that police officers carry out their statutory employment duties. ${ }^{18}$

5. A duty owed by government safety inspectors to protect workers from the consequences of criminal conduct perpetrated by others. ${ }^{19}$

\section{The Unique Public Duties of Care}

\section{A. A Unique Public Duty on the Part of Police Officers TO EnSURE THE SAFETy OF Motorists AfTER A Highway Traffic ACCident}

In Schacht, a 6-3 majority of the Supreme Court of Canada recognized a unique public duty on the part of police officers to ensure the safety of motorists after a highway traffic accident. $^{20}$

Vancouver (City) $v$ Ward, 2010 SCC 27, [2010] 2 SCR 28.

See Bruce Feldthusen, "Public Authority Immunity from Negligence Liability: Uncertain, Unnecessary, and Unjustified" (2013) 92:2 Can Bar Rev 211 [Feldthusen, "Public Authority Immunity"] (here, I have argued that the defence of statutory authority would be a preferable approach in negligence law to common law policy immunity).

Odhavji, supra note 10 (the duty on the part of the chief of police to use reasonable care to insure that police officers carry out their statutory employment duties is a peculiar claim for psychiatric damage). Siebrasse, supra note 5, suggests the descriptive term "regulatory liability." See also Nicholas J McBride \& Roderick Bagshaw, Tort Law, 5th ed (Harlow, UK: Pearson Education, 2015) at ch 7.

O'Rourke v Schacht, [1976] 1 SCR 53 [Schacht].

Kamloops (City of) v Nielsen, [1984] 2 SCR 2 [Kamloops].

Just v British Columbia, [1989] 2 SCR 1228 [Just].

Odhavji, supra note 10, discussed in Part II.D, below.

Fullowka v Pinkerton's of Canada Ltd, 2010 SCC 5, [2010] 1 SCR 132 [Fullowka].

Supra note 15. This is probably the first case where the Supreme Court of Canada created a unique public duty of care. Interestingly, while the other unique public duty cases discussed in this article trace their roots directly or indirectly to the decision in Anns, supra note 3, while Schacht was decided earlier. The majority did, however, approve the distinguishable and wrongly decided decision in Dutton $v$ Bognor Regis Urban District Council, [1972] 1 QB 373 (CA) [Dutton]. 
In the original accident a car knocked down one of several signs warning of an open excavation across the highway. The police investigated the accident and then left the scene without notifying the Department of Highways about the damage to the sign. Schacht then drove into the excavation. The Court held that a timely warning would have led to the sign being replaced thereby preventing the second accident. ${ }^{21}$ The supervising constable was held liable for failing to give the Department a timely warning, and the Commissioner of Police was held vicariously liable under The Police Act. ${ }^{22}$ This section is essentially identical to section 5 of the Proceedings Against the Crown Act. ${ }^{23}$

Justice Spence gave the judgment for the majority. He relied primarily if not exclusively on section 3(3)(a) of The Police Act which required the police force to "maintain a traffic patrol." ${ }^{24}$ It was not possible to point to an analogous private party duty of care. He quoted Lord Diplock in Home Office v. Dorset Yacht Co. ${ }^{25}$ that the issue was "at bottom a matter of public policy which we, as judges, must resolve. ${ }^{26} \mathrm{He}$ also referred to Dutton, ${ }^{27}$ as well as two other police cases that did not address whether police officers owe a duty of care based on the officers' failure to perform statutory obligations. ${ }^{28}$

One must look for private party analogies in the duty to rescue or duty to warn case law. At common law a private defendant has a duty to rescue someone foreseeably endangered when the defendant "by his fault" created the situation of peril. ${ }^{29}$ A duty to rescue where the defendant without fault creates the situation of peril has been considered but not accepted in Canada. ${ }^{30}$ The law does recognize a duty on a manufacturer to warn consumers of dangerous defects whether or not the defect was caused by the manufacturer's negligence. ${ }^{31}$ However, in such cases the manufacturer is involved in creating the situation of peril. A defendant who induces the plaintiff to rely on him or her for protection from harm caused by a third party might owe the plaintiff a duty of care if the plaintiff relied to his or her detriment. ${ }^{32}$ There was no such induced or actual reliance in Schacht. The majority ultimately created a new and unique public duty of care.

Schacht, ibid at 72 .

RSO 1970, c 351, s 47 (1)

RSO 1990, c P27 [Proceedings Act].

Supra note 22, s 3(3)(a); Schacht, supra note 15 at 71.

[1970] AC 1004 (HL (Eng)) [Home Office].

Schacht, supra note 15 at 64, citing Home Office, ibid at 1058.

Supra note 20.

Haynes v Harwood, [1935] 1 KB 146 (CA); Priestman v Colangelo, [1959] SCR 615.

Videan v British Transport Commission, [1963] 2 QB 650 at 669 (CA), quoted with approval in Horsley $v$ MacLaren, [1972] SCR 441 at 444 [Horsley].

Horsley, ibid. See also Oke $v$ Weide Transport Ltd (1963), 41 DLR (2d) 53 (Man CA), Freedman JA, dissenting; Ziemer $v$ Wheeler, 2014 BCSC 2049, 2014 BCSC 2049 (CanLII) (here, the Court was seemingly unaware that it was breaking new ground when it found the defendant breached a duty to warn other motorists after a non-negligent collision).

See e.g. Rivtow Marine Ltd v Washington Iron Works, [1974] SCR 1189 [Rivtow Marine].

These reliance points are developed more fully in Feldthusen, "Hedley Byrne," supra note 3. Siebrasse, supra note 5 suggests there should be a presumption of liability whenever there is specific reliance. There are numerous examples of public authorities being held vicariously liable for negligent misrepresentation. These are not unique public duties. See Bruce Feldthusen, Economic Negligence, 6th ed (Toronto, Ont: Carswell, 2012) at 300, n 97. 
The defendant police force in Schacht was an agent of the Crown. ${ }^{33}$ Historically, the Crown outside of Quebec is immune from tort liability except to the extent that the Crown itself consents to being held liable. It was not until the mid-twentieth century that Crown immunity was partly abrogated by legislation in Canada and the common law provinces. ${ }^{34}$ The Crown cannot be held liable in negligence except in compliance with the relevant Crown liability statutes. ${ }^{35}$ The federal Crown, and the Crown in eight of the nine common law provinces have consented only to being held vicariously liable for torts committed by their servants or agents. ${ }^{36}$ British Columbia has consented to being held directly liable across the board. ${ }^{37}$ The Crown does not accept being held liable for "[p] eculiarly governmental activity" where there exists "no clear private analogue." ${ }^{38}$ Justice Martland, dissenting in Schacht, observed that section 3(3)(a) of The Police Act imposed duties on the police force, not on individual constables for whose action the police force would be vicariously liable. If there was no foundation whatsoever for a duty on the part of the employee, he reasoned, the Crown could not be held vicariously liable. ${ }^{39}$ Vicarious liability was the only responsibility it had accepted under statute. Foreshadowing the way in which a similar argument would be dismissed summarily in Swinamer,${ }^{40}$ the majority did not even find it necessary to deal with this point. And so began the neutering by stealth of the Crown liability statutes in Canada.

Schacht presents the universal difficulty of justifying unique public duties of care. In the absence of any analogous private party duties of care, the only foundation for the new public duty in Schacht was the statute itself. Shortly after Schacht the Supreme Court would hold that it is impermissible in law to employ a statutory public duty as the sole foundation for the

The executive branch of the government, commonly referred to as the Crown, is a distinct type of statutory public authority. The executive branch includes departments of government controlled by a Minister and statutory bodies expressly declared in their enabling legislation to be an agent of the Crown. Many important statutory public authorities such as municipalities, school boards, hospitals, and regulatory agencies, are not usually agents of the Crown: Hogg, Monahan \& Wright, supra note 6 at 13. Ibid at 4-11.

As stated in Stephens' Estate v MNR (1982), 40 NR 620 (" $\mathrm{t}]$ he vicarious liability of the Crown and the right of action against it are created by paragraph 3(1)(a) of the Crown Liability Act and would not exist apart from it" at para 19). See also Williams v Canada (Attorney General) (2005), 76 OR (3d) 763 (Sup Ct J) [Williams], rev'd on other grounds 2009 ONCA 378, 95 OR (3d) 401, leave to appeal to SCC refused 33257 (17 Decenber 2009).

36 Crown Liability and Proceedings Act, RSC 1985, c C-50, s 10; Proceedings Against the Crown Act, RSA 2000, c P-25, s 5(1)(a); Proceedings Against the Crown Act, CCSM, c P140, s 4(1)(a); Proceedings Against the Crown Act, RSNB 1973, c P-18, s 4(1)(a); Proceedings Against the Crown Act, RSNL 1990, c P-26, s 5(1)(a); Proceedings Against the Crown Act, RSNS 1989, c 360, s 5(1)(a); Crown Proceedings Act, RSPEI 1988, c C-32, s 4(1)(a); The Proceedings against the Crown Act, RSS 1978, c P-27, s $5(1)$ (a). Canada and all the common law provinces except BC also have a provision substantially identical to section 10 of the federal Act which reads as follows:

No proceedings lie against the Crown ... in respect of any act or omission of a servant of the

Crown unless the act or omission would, apart from the provisions of this Act, have given rise to

a cause of action for liability against that servant or the servant's personal representative or succession.

37 Crown Proceeding Act, RSBC 1996, c 89, s 2(c). See Hogg, Monahan \& Wright, supra note 6 at $159-60,177$. See also $K L B$, supra note 4 at para 12 . An attempt to draw a significant distinction between the British Columbia and Nova Scotia statutes on this very basis was rejected outright by the Supreme Court of Canada in Swinamer v Nova Scotia (Attorney General), [1994] 1 SCR 445 at 460 [Swinamer]. Hogg, Monahan \& Wright once thought the distinction between direct and vicarious liability was crucial, but today the authors concede that it is irrelevant (ibid at 182-83). For an extensive discussion of the evaporation of the distinction between vicarious and direct liability, see Williams, supra note 35 at paras 32-40. Note that direct liability could be a unique public duty, or a duty analogous to a recognized private party duty.

38 Hogg, Monahan \& Wright, ibid at 261 uses these terms and supports this proposition, albeit without reference to the legislation. See also Siebrasse, supra note 5 at 86 . Schact, supra note 15 at 81 .

Supra note 37. 
duty of care in negligence. ${ }^{41}$ The only other option, given that the Court is ignoring the Crown liability legislation, is to provide unique public justifications for unique public duties of care.

Schacht presents a relatively strong case for a unique public duty. The two major justifications for the "no duty to rescue" rule in private party negligence, personal autonomy ${ }^{42}$ and salience, ${ }^{43}$ do not apply to public bodies. Nor does the "activity level" argument that such a duty would inhibit the authority from providing gratuitous benefits. The police will continue to respond to traffic accidents. The duty seems to promote efficient deterrence. Very little was required of the constable to prevent very serious harm. On the other hand, rights-based theorists would argue that negligence law should only protect recognized rights, and that no right to such a warning exists in law. They would argue that courts should not make policy decisions that redistribute wealth. Unique public duties are not rights-based, and they always have budgetary, and therefore distributional, consequences. ${ }^{44}$

If one is open to courts pursuing deterrence goals in negligence law, it seems reasonable to require the Court that employs them to explain how the new liability rule will work. Are public authorities deterred by liability rules in the same manner in which it is assumed private parties are affected? The rule in Schacht will force police forces to redirect their budget away from other operations. What looks like a low cost obligation to notify the Department of Highways that a warning sign is down might impose a considerably higher cost if an insurer has to underwrite all the potential risks that might arise when a constable is maintaining a traffic patrol. Is this reallocation of budget a "good" thing? Are the courts in a good position to know? As is typically the case, not one word was offered along these lines to justify a unique public duty of care in Schacht.

\section{B. A Unique Public Duty OWed by Municipalities Who Undertake a Program of Housing Inspection OWed to Prospective Purchasers}

In Cooper, the Supreme Court of Canada confirmed that "a municipality has been held to owe a duty to prospective purchasers of real estate to inspect housing developments without negligence." 45 This duty does not compel municipalities to conduct inspections. However, a duty is recognized to exist once an inspection program is in place. While this duty of care was clearly derived from Anns ${ }^{46}$ and adopted first by the Supreme Court in Kamloops, ${ }^{47}$ the

$R v$ Saskatchewan Wheat Pool, [1983] 1 SCR 205 [Saskatchewan Wheat Pool]. This rule was reaffirmed but not necessarily followed in Odhavji, supra note 10 at para 31. Lewis Klar has published extensively about Saskatchewan Wheat Pool. Several of these articles are cited in Lewis N Klar, Tort Law, 5th ed (Toronto, Ont: Carswell, 2012) at 307, n 58.

Childs v Desormeaux, 2006 SCC 18, [2006] 1 SCR 643 [Childs]. See also Siebrasse, supra note 5 at 88 Margaret Isabel Hall, "Duty to Protect, Duty to Control, and the Duty to Warn" (2003) 82:3 Can Bar Rev 645 at 666 [Hall, "Duty to Protect"] citing Stovin $v$ Wise, [1996] AC 923 (HL (Eng)), Nichols LJ, dissenting [Stovin]. This is the "why me?" argument that deals with the practical problem of singling out one or a few defendants from among many similarly situated others. See Siebrasse, ibid at 88-89.

See e.g. Weinrib, supra note 8; Beever, supra note 8.

Supra note 10 at para 36.

Supra note 3.

Supra note 16. See also Ingles v Tutkaluk Construction Ltd, 2000 SCC 12, [2000] 1 SCR 298. 
Canadian rule is more closely based on the now discredited earlier decision of the English Court of Appeal in Dutton. ${ }^{48}$

This is obviously a unique duty of care. There are only two recognized ways in which a private party may come under a duty to another to inspect property with due care. First, the homeowner may contract with the defendant to perform inspection services. Second, the defendant may undertake by word or conduct to perform such a gratuitous service for the homeowner, thereby inducing the homeowner to rely on the undertaking to her detriment. ${ }^{49}$ There is no duty in private party negligence law that requires one who voluntarily and gratuitously undertakes to provide a benefit to another to complete the undertaking by providing the benefit with due care. The service undertaken may be withdrawn without consequence unless the defendant has suffered additional harm directly inflicted, or detrimental reliance loss induced, by the defendant. In Dutton, the defendant did not induce the plaintiff to rely. ${ }^{50}$ There was no allegation that the plaintiff had considered, let alone relied on the municipality to inspect. Lord Denning cited hypothetical examples of liability for physical harm in the absence of reliance caused by products such as food and lifts that had been negligently certified. ${ }^{51}$ If the house in Dutton had collapsed and injured someone there would have been liability on the part of the builder, and by analogy possibly on the part of the municipality, for personal injury or damage to other property. The cost of repairing the house itself is economic loss. Dutton is not an example of a municipality injuring anyone. The municipality caused no additional harm. Dutton is a case of the municipality failing to provide a gratuitous benefit, a variation of a failure to rescue.

The Court emphasized the degree of control that the municipality had over the situation. A recognized special relationship of control (such as parent-child, teacher-student, doctorpatient, boat operator-passenger, for example) may well justify recognition of a duty to exercise such control reasonably to protect the vulnerable party. An analogous special relationship of control in the public sphere supports vicarious liability for failing to protect, as discussed previously, or to control a government ward such as a prisoner. ${ }^{52}$ However, the relationship between a municipality and a builder is not one of control in the same sense. ${ }^{53}$ A better analogy would be to cases where Health Canada certified medical devices or drugs for public consumption that turn out to be dangerous to consumers. Canadian courts have refused to recognize proximity between the consumers and the public defendant. ${ }^{54}$ It is difficult, if not impossible, to reconcile these decisions with Dutton and the Canadian municipal inspection cases that approve and follow it. At the end of the day, the duty of care in Dutton rests on the statutory public duty and nothing more. This is not permissible under Canadian law. ${ }^{55}$

\footnotetext{
Supra note 20 .

See Feldthusen, Economic Negligence, supra note 32, ch 2, 3.

See Feldthusen, "Hedley Byrne," supra note 3 for an explanation of why the defendant must induce the plaintiff to rely.

Dutton, supra note 20 at 395.

See Home Office, supra note 25. See Part II.D, below.

See Anns, supra note 3 at 754.

See e.g. Klein v American Medical Systems, Inc (2006), 84 OR (3d) 217 (Sup Ct J (Gen Div)); Wuttunee $v$ Merck Frosst Canada Ltd, 2007 SKQB 29, [2007] 4 WWR 309; Attis v Canada (Minister of Health), 2008 ONCA 660, 93 OR (3d) 35 [Attis]; Drady v Canada (Minister of Health), 2008 ONCA 659, 300 DLR (4th) 443 [Drady].

Odhavji, supra note 10 at para 31, citing Saskatchewan Wheat Pool, supra note 41.
} 
The allegations in Anns were somewhat different from those in Dutton. It was not established in Anns whether any inspection had in fact been carried out. Lord Wilberforce applied his now famous two-step framework for recognizing a duty of care. First, the plaintiff was required to establish proximity. He never clearly defined proximity. One could argue that Lord Wilberforce meant by proximity nothing more than the double foreseeability rule from Donoghue v. Stevenson. ${ }^{56}$ Despite his preference for a single general conception of negligence law, Lord Wilberforce paid a great deal of attention to the unique aspects of government liability. ${ }^{57} \mathrm{He}$ derived that proximity from the statute in the same way that it was derived in Dutton.

Although an expanded scope of negligence liability is often attributed to the decision in Anns, Lord Wilberforce actually contemplated a very limited scope of liability for public authorities. In the case of a discretionary statutory public power, he recognized a private law duty to give proper consideration to the question of whether to inspect. ${ }^{58}$ This is obviously a unique public duty of care, arguably a desirable one, but one for which there existed no precedent in the common law. He went on:

\footnotetext{
Passing then to the duty as regards inspection, if made. On principle there must surely be a duty to exercise reasonable care... There may be a discretionary element in its exercise - discretionary as to the time and manner of inspection, and the techniques to be used. A plaintiff complaining of negligence must prove, the burden being on him, that action taken was not within the limits of a discretion bona fide exercised, before he can begin to rely upon a common law duty of care. But if he can do this, he should, in principle, be able to sue. 59
}

In Canada today we would regard this as a discussion of "policy immunity." We would define the scope of policy immunity much narrower than the broad discretionary immunity favoured by Lord Wilberforce. ${ }^{60}$ And we would see it as a step two consideration where the defendant would have the onus of making the case for immunity after the plaintiff had established a prima facie duty of care based on proximity at step one.$^{61}$ Lord Wilberforce left the onus on the plaintiff to prove that no discretion was involved.

Given the extremely limited scope of potential liability anticipated by Lord Wilberforce, one can sympathize with him if he believed that he had dealt adequately with the uniquely public aspects of the claim. However, Anns still suffers from precisely the same shortcoming as Dutton. Absent a contract or an undertaking intended to induce transaction-specific detrimental reliance, there is no authority that requires one person to confer a gratuitous benefit of an inspection on another. Basing the duty on the statute alone, at least in Canada, ought not to be allowed. ${ }^{62}$ Or if it is to be allowed, it should be acknowledged as a unique public duty of care and justified as such. Anns proceeds on the assumption that, but for this

[1932] AC 562 [Donoghue].

See especially Anns, supra note 3 at 754, 757.

Ibid at 755 .

Ibid.

See $R$ v Imperial Tobacco Canada Ltd, 2011 SCC 42, [2011] 3 SCR 45 at para 80 [Imperial Tobacco]; Feldthusen, Economic Negligence, supra note 32, at ch 6 . Lord Wilberforce did not use immunity language in his discretion discussion, although he did refer to the policy-operational continuum.

61 Imperial Tobacco, ibid.

See supra note 55. 
being a public defendant, there would obviously be a duty to inspect with care. This is not true.

While there is no question that the duty to inspect from Anns was approved in Kamloops, the ratio in Kamloops is quite different. ${ }^{63}$ Kamloops involved another inadequate house foundation, but there it was inspected and found to be unsatisfactory. The defendant issued a stop work order but it was never enforced. ${ }^{64}$ Ultimately the house subsided and the owner sued the City and the builder. The majority characterized the failure to enforce the bylaw as operational negligence and held the municipality liable. The dissent held that a duty to enforce a bylaw was entirely different from a duty to inspect with care, and entirely discretionary. It seems obvious that the duty to enforce a bylaw was a new and unique public duty of care in negligence, imposed with no greater foundation and even less respect for the unique nature of government than the duty to inspect. ${ }^{65}$

In Kamloops, both the majority and the dissent approved of the decision in Anns insofar as it pertained to a duty to inspect. ${ }^{66}$ The Supreme Court also correctly identified the damage to the foundations as an economic loss, not property damage. The House of Lords did not adopt this position until later. ${ }^{67}$ The Supreme Court added nothing to the flimsy English foundation for the duty to inspect. Although Justice Wilson stated that the duty was a private duty as opposed to a statutory duty, the duty was again derived entirely from the statute. ${ }^{68}$ There was no induced reliance, or detrimental reliance in fact. There was no common law analogy. If anything the duty may have been based on "general reliance." ${ }^{69}$ General reliance means that the general public simply assumes that public authorities will conduct their operations without negligence and, as in New Zealand, the public also relies on the state to compensate injured parties when the authorities do not. ${ }^{70}$ This is not the situation-specific reliance between parties in a closely proximate relationship that produces detrimental reliance. It is general. General reliance of this sort has been the subject of judicial musing in

$63 \quad$ Supra note 16.

The possibility that there had been pressure from an alderman who was the father of builder (Nielsen $v$ Kamloops (City of) (1981), 129 DLR (3d) 111 at 119). The dissent in the Supreme Court of Canada rejected this explicitly.

65

The unique duty to enforce bylaws is not considered in this article. See Welbridge Holdings Ltd $v$ Greater Winnipeg, [1971] SCR 957; Rothfield v Manolakis, [1989] 2 SCR 1259; cf Holland v Saskatchewan, 2008 SCC 42, [2008] 2 SCR 551 at para 14 (duty to implement a judicial decree). Supra note 16. The Court also relied on McCrea $v$ White Rock (City of) (1974), 56 DLR (3d) 525 (BCCA), a decision which in turn had relied upon Dutton, supra note 20.

67 In the US it has always been the rule that damage to the structure itself was economic loss and as such not recoverable from the builder in either strict tort or negligence. See Feldthusen, Economic Negligence, supra note 32, ch 4; Jay M Feinman, "The Economic Loss Rule and Private Ordering" (2006) 48:4 Ariz L Rev 813; Dan B Dobbs, "An Introduction to Non-Statutory Economic Loss Claims" (2006) 48:4 Ariz L Rev 713. At the time Anns was decided, Canada followed the US rule: Rivtow Marine, supra note 31. Lord Wilberforce correctly distinguished Rivtow Marine at 759-60 and held that the duty to inspect (enforce the bylaw) is different from the manufacturer/builder's duty. Economic loss could be recovered for breach of the duty to inspect/enforce if the statute dealt with preventing economic loss. Anns was overruled on this point in the UK in Murphy v Brentwood District Council, [1991] 1 AC 398 (HL (Eng)) and damage to the product/structure itself is no longer recoverable in negligence. Ironically, the Supreme Court of Canada reversed itself after Anns and Kamloops and held that the building owner could recover the cost of repairing dangerous defects from the builder: Winnipeg Condominium, supra note 3 . Kamloops, supra note 16 at 33-34.

Siebrasse, supra note 5 says that the only justification for the decision was general reliance and he criticizes the Court for its cursory treatment of this crucial issue.

Invercargill City Council v Hamlin, [1994] 3 NZLR 513 (CA), aff'd [1996] AC 624 (PC). Although general reliance typically arises in public authority negligence actions, it is discussed in both the private and public sectors in Childs, supra note 42 at para 40. 
the Australian High Court ${ }^{71}$ and the House of Lords, ${ }^{72}$ but never adopted expressly as a ground for liability in either of those jurisdictions. The Supreme Court of Canada has never adopted general reliance expressly. Whatever influence general reliance has, it is exercised in the shadows of public authority negligence law.

Municipal governments are not agents of the Crown, so recognizing a unique duty to inspect does not violate sovereign immunity. However, a good case can still be made for restricting the liability of all public authorities to acts or omissions that would be tortious if done by a private party. ${ }^{73}$ Such a rule would be far easier to apply than the policy immunity rule we currently employ. ${ }^{74}$ More important is the political justification. All public agencies would be both "under the law" and under "the same law that applies to private citizens," a principle Dicey called the "idea of legal equality." " Unique public duties violate this idea of equality.

The rights-based theorists would argue that it is the role of the legislature, not the courts, to redistribute wealth on policy grounds, and that the courts should not make such policy determinations in crafting duties of care. ${ }^{76}$ Others would argue that the courts must be institutionally competent to obtain and interpret strong evidence about the likely policy outcomes before engaging in this sort of social engineering. No such evidence was discussed by the Supreme Court in Kamloops. In Canada, the question of home construction warranties has commanded legislative attention and various schemes, especially for new residential construction, have been legislated. ${ }^{77}$ The builder owes a subsequent purchaser a duty to prevent dangerous defects. Even so, the prudent purchaser will still purchase a private inspection. In cases where there is only a statutory power, not duty, to inspect, potential liability may incline some municipalities to forgo inspection programs altogether. The case on the merits for a judicially created unique public duty of care is less compelling here than it was in Schacht. ${ }^{78}$ The political and legal communities need an open, informed conversation about unique public duties of care.

Sutherland Shire Council v Heyman (1985), 60 ALR 1, Mason J (however, this was rejected in Pyrenees Shire Council v Day (1998), 151 ALR 147).

Stovin, supra note 42 at $953-55$, Hoffman LJ.

73 I would include meaningfully analogous duties owed by private parties. See Hogg, Monahan \& Wright, supra note 6 at 261 (the Crown does not accept liability for "[p] eculiarly governmental activity" where there exists "no clear private analogue" at 261). Strictly speaking the legislation does not extend to analogous duties in the case of the Crown, but this is irrelevant since the courts ignore the legislation. The Supreme Court of Canada has established an immunity from negligence liability for "core policy" decisions: see e.g. Just, supra note 17; Imperial Tobacco, supra note 60. Today immunity is usually invoked as an alternative basis of decision, supporting the step one conclusion that there was insufficient proximity to found a duty of care. Rarely, as in Imperial Tobacco, immunity is invoked despite a finding of private party proximity. This seems to be a direct violation of the Crown's consent to be held liable in the Crown liability legislation. Although immunity is exculpatory, in a case like Imperial Tobacco the Court still asserts control over the scope of government liability. See generally Feldthusen, "Public Authority Immunity," supra note 12.

75 Hogg, Monahan \& Wright, supra note 6 at 218-19, n 319; AV Dicey, Introduction to the Study of the Law of the Constitution, 10th ed (London: McMillan, 1959) 193. See also McBride, supra note 2; McBride \& Bagshaw, supra note 14 at 227 discussing the "why pick on me" principle.

76 See the authors cited at supra note 8.

77 See Muncipal Act, RSBC 1996, c 323, s 289 (in British Columbia the duty to enforce the bylaw was overturned by statute, but the power to inspect was left intact). Supra note 15. 


\section{A Unique Public Duty on the Part of Governmental Authorities Who have Undertaken a Policy of Road Maintenance to EXECUTE THE MAINTENANCE IN A NON-NEgLigent MANNER ${ }^{79}$}

This duty originated with the Supreme Court's decision in Just, a decision better known for its discussion of policy immunity. ${ }^{80} \mathrm{Mr}$. Just was killed and his daughter was injured when a boulder on a slope adjoining a provincial highway came loose and crashed down on his car. The government had a system of inspection in place, but the trial judge, Justice McLachlin, as she then was, did not make a finding on whether the system was reasonable because she held that the government enjoyed policy immunity from negligence. ${ }^{81}$

At the Supreme Court, Justice Cory adopted and applied the two-step duty formulation from Anns. The entire step one proximity analysis was found in the following paragraph:

In the case at bar the accident occurred on a well used major highway in the province of British Columbia. All the provinces across Canada extol their attributes and attractions in the fierce competition for tourist business. The skiing facilities at Whistler are undoubtedly just such a magnificent attraction. It would be hard to imagine a more open and welcoming invitation to use those facilities than that extended by the provincial highway leading to them. In light of that invitation to use both the facilities and the highway leading to them, it would appear that apart from some specific exemption, arising from a statutory provision or established common law principle, a duty of care was owed by the province to those that use its highways. That duty of care would extend ordinarily to reasonable maintenance of those roads. The appellant as a user of the highway was certainly in sufficient proximity to the respondent to come within the purview of that duty of care. In this case it can be said that it would be eminently reasonable for the appellant as a user of the highway to expect that it would be reasonably maintained. For the Department of Highways it would be a readily foreseeable risk that harm might befall users of a highway if it were not reasonably maintained. That maintenance could, on the basis of the evidence put forward by the appellant, be found to extend to the prevention of injury from falling rock. ${ }^{82}$

No authority was referred to support an existing common law tort duty for municipalities to maintain their highways. This is not surprising. The Supreme Court created it. This is obviously a unique public duty of care. Private parties do not have a duty to maintain highways unless they have contracted to do so, or they have induced the plaintiff to rely on them as having assumed such a duty to the plaintiff's detriment. As noted in discussing the housing inspection cases, there is no duty in private party negligence law that requires one who voluntarily and gratuitously undertakes to provide a benefit to another to complete the undertaking by providing the benefit with due care.

It has been argued elsewhere that the claim in Just should have been dismissed at the proximity stage, thus rendering unnecessary the ultimately unhelpful discussion of policy

This duty was endorsed in Cooper, supra note 10 at para 36 when the Supreme Court referred to Just, supra note 17; Swinamer, supra note 37.

80 Just, ibid.

81 A subsequent retrial found the inspection practice did breach the standard of reasonable care, but that was not relevant to the duty discussion in the Supreme Court: see Just v British Columbia (1991), 60 BCLR (2d) 209. 
immunity. ${ }^{83}$ It is questionable whether a modern court would find proximity if the facts in Just manifested themselves as an issue of first impression today. The Ontario Court of Appeal has identified the key factor leading to a finding of proximity in public authority cases as "a relationship and connection between the regulator and the individual that is distinct from and more direct than the relationship between the regulator and that part of the public affected by the regulator's work." ${ }^{\prime 4}$ There is ample support for this proposition in the public defendant case law. ${ }^{85}$ There was no pre-accident connection between the parties in Just. There was no transaction-specific reliance. The defendant did not push the rock down the slope, but rather failed to prevent it from falling. Foreseeability of harm is insufficient to ground a duty of affirmative action.

Sometimes proximity seems to be nothing more than a device used to narrow the ambit of liability beyond what it would be with foreseeability alone.$^{86}$ The proximity finding in Just does not even do that. Highway users are the only foreseeable plaintiffs in the highway maintenance cases. Proximity should properly be based on a meaningful application of the neighbour principle. It is ridiculous to speak of the entire general public, or all the members of a class of persons being regulated or who might foreseeably be affected by such regulation, as the defendant's neighbours in law. True, liability to such a large, possibly indeterminate class may pose a practical problem. However, that is not the fundamental problem in Just. The relationship is simply not proximate. ${ }^{87}$

The best explanation for Just is that it creates a unique public duty based on some unarticulated concept of "general reliance." ${ }^{\circ 8}$ If so, why was general reliance employed here, but not later in other similar situations? For example, the courts do not recognize proximity where members of the public purchase defective medical devices that have been approved for sale by Health Canada. ${ }^{89}$

Having established a unique public duty to maintain highways in a single paragraph, the Supreme Court then devoted two paragraphs to rendering impotent the Crown Proceeding Act. ${ }^{90}$ Section 2 of that Act states that "the Crown is subject to all those liabilities to which

$83 \quad$ Feldthusen, "Public Authority Immunity," supra note 12.

84 Taylor v Canada (Attorney General), 2012 ONCA 479, 111 OR (3d) 161 at para 80 [Taylor]. In support the Court cited Drady, supra note 54 and Attis, supra note 54. Taylor also relied on Hill, supra note 4. The Court in Hill distanced itself from two superficially similar decisions involving the police: Odhavji, supra note 10 (the duty owed by the chief of police to supervise employees to prevent harm to third parties); Doe v Metropolitan Toronto (Municipality) Commissioners of Police (1998), 39 OR (3d) 487 (Ct J (Gen Div)) [Jane Doe] (the duty owed to potential victims to investigate crimes with due care). See also the authorities cited in Adam v Ledesma-Cadhit, 2014 ONSC 5726, 2014 ONSC 5726 (CanLII). See e.g. Heaslip Estate v Mansfield Ski Club Inc, 2009 ONCA 594, 96 OR (3d) 401; Odhavj, supra note 10 (the discussion of proximity).

87 The most famous concern about "a liability in an indeterminate amount for an indeterminate time to an indeterminate class" may be found in Ultramares Corporation v Touche, 174 NE 441 at 444 (NY 1931) (Cardozo CJ). It has been argued that these concerns were expressed to suggest that there was an error in the duty (proximity) analysis if such exposure existed, not expressed for the purpose of limiting the exposure generated by the (improper) duty formulation. In other words, it was a relational concern, not a practical concern. See Jason W Neyers, "Donoghue v. Stevenson and the Rescue Doctrine: A Public Justification of Recovery in Situations Involving the Negligent Supply of Dangerous Structures" (1999) 49:4 UTLJ 475 at 483, n 51 (citing Peter Benson, "The Basis for Excluding Liability for Economic Loss in Tort Law" in David G Owen, ed, Philosophical Foundations of Tort Law (Oxford: Clarendon Press, 1995) 427 at 434; Robby Bernstein, Economic Loss (London, UK: Longman Group, 1993) at 14. See also Weinrib, supra note 8 at 231.

88 See supra notes $67-68$ and accompanying text.

$89 \quad$ See supra note 54

$90 \quad$ RSBC 1979 , c 86. 
it would be liable if it were a person,"91 and section 3(2)(f) states that nothing in section 2 "subjects the Crown, in its capacity as a highway authority, to any greater liability than that to which a municipal corporation is subject in that capacity." $"{ }^{2}$ Justice Cory dismissed the Crown Proceeding Act summarily as follows: "On their face these statutory provisions do not appear to absolve the respondent from its duty of care to maintain the highways reasonably. Rather, by inference they appear to place an obligation on the province to maintain its highways at least to the same extent that a municipality is obligated to repair its roads. ${ }^{.93}$

Of course there was no antecedent duty to maintain the highway until Just created one, and hence nothing to absolve. The "same extent that a municipality is obligated to maintain its roads" was no obligation whatsoever in British Columbia. ${ }^{94}$ Yet, without further discussion, the Supreme Court rendered meaningless the Canadian Crown liability statutes.

In fairness to the Supreme Court in Just, like the House of Lords in Anns, the Court was not indifferent to the unique aspects of public defendants. Justice Cory acknowledged that the legislature may expressly exempt a public defendant from liability, and that the Court must consider whether the allegations of negligence are immune from negligence law because they fall in the authority's policy realm. The Supreme Court held that the allegation in Just concerned operational negligence, not policy, and the matter was returned to trial where a breach of the standard of care was eventually determined.

The Supreme Court of Canada solidified this suspect duty to maintain highways by simultaneously releasing reasons approving and applying Just subsequently in two similar actions, Swinamer, ${ }^{95}$ and Brown v. British Columbia (Minister of Transportation and Highways). ${ }^{96}$ Although the same duty based on foreseeability or general reliance was recognized, the government was not held liable in either Swinamer or Brown. The Supreme Court held that the inspection programs at issue enjoyed policy immunity and that there had been no operational negligence. ${ }^{97}$

Swinamer provided the Court with an opportunity to tie up a loose end left after Just concerning the neutering of the Crown liability statutes. The Crown attempted to rely on the Nova Scotia legislation by distinguishing it from the British Columbia legislation. It argued that the Nova Scotia legislation provides that the province is only liable for a tort committed by its officers or agents if that tortious act of the servant or agent would in itself have given rise to a cause of action. In essence, it argued that the Court could not create unique government duties in Nova Scotia. The British Columbia legislation provides that the Crown is subject to all those liabilities to which it would be liable if it were a person. Justice Cory declined to attach any significance to the difference in wording: "Obviously the Crown can only be liable as a result of the tortious acts committed by its servants or agents since it can

Ibid, s 2 .

Ibid, s 3(2)(f).

Just, supra note 17 at 1237 .

See Barratt v North Vancouver (District of), [1980] 2 SCR 418 (unconvincingly distinguished in Just, ibid at $1237-38$ ).

Supra note 37.

[1994] 1 SCR 420 [Brown].

The distinction between Just, supra note 17 on the one hand and Swinamer, supra note 37 and Brown, ibid on the other is not obviously apparent. 
only act through its servants or agents. ${ }^{, 98}$ Section 5 of the Public Highways Act, which states that "nothing in this Act compels or obliges the Minister to construct or maintain any highway or to expend money on any highway" $" 99$ was dismissed by the Supreme Court in Swinamer as insufficiently clear to exempt the government from liability. ${ }^{100}$ The results in Swinamer and Brown show that the Court was not overly anxious to actually impose liability. However, the Court seemed determined to create and retain the power to do so in the face of legislation apparently to the contrary.

Ignoring the sovereign immunity argument, was it a good idea to create this unique public duty of care? This is difficult to answer without evidence. How do public authorities respond to potential liability? Might no-fault first party accident insurance be a more efficient manner with which to deal with accidents like this? Will potential liability reduce the number of discretionary highway maintenance programs adopted by the Crown? None of these questions were considered by the Supreme Court.

\section{A Duty of Care on the Part of the Chief of Police to Ensure that Police OfFicers Cooperate WITH AN SIU INVESTIGATION}

In Odhavji, the Supreme Court recognized a duty of care on the part of the chief of police to ensure that police officers cooperated with an SIU investigation into a police shooting of Mr. Odhavji. ${ }^{101}$ Justice Iacobucci, who gave the judgment for the Court, applied the Anns test. He held that for the purposes of the motion to strike out the plaintiffs, close relatives of the deceased, it had to be established that it was foreseeable that they would suffer compensable psychiatric harm if the SIU investigation was not carried out fairly. ${ }^{102}$ This is a highly contentious finding. The plaintiff in Mustapha v. Culligan of Canada Ltd. should have been so lucky considering he actually had demonstrable psychiatric harm. ${ }^{103}$ There exists no recognized meaningfully analogous claim for foreseeable psychiatric damage in Canadian negligence law. This is another unique public duty of care effectively founded entirely on the Police Services Act. ${ }^{104}$

Swinamer, supra note 37 at 461. See also the baffling conclusion in Brown, supra note 96 ("[a]lternatively, if the Crown Proceeding Act had exempted the Crown from liability for all tortious acts, there would be a statutory exemption. However, there is no statutory exemption in that Act which would exempt the Crown for negligently failing to maintain its roads" at 440 [emphasis in original]).

RSNS 1989, c 371, s 5.

Supra note 37 at $459-60$.

Supra note 10 (this decision is better known for its discussion of the elements necessary to establish the intentional tort of misfeasance in public office).

Formally, a decision on a motion to strike out differs from a judgment on the merits. It is tempting to say that the former has less precedential value than the latter and to discount Odhavji, ibid as merely a decision on a preliminary motion. This would be a serious mistake. Consider Donoghue, supra note 56; Anns, supra note 3; Cooper, supra note 10 as examples of decisions on preliminary motions that have shaped modern Canadian negligence law. Citing Odhavji in Imperial Tobacco, supra note 60 at para 17, the Supreme Court held that a "claim will only be struck if it is plain and obvious, assuming the facts pleaded to be true, that the pleading discloses no reasonable cause of action." Presumably then Justice Iacobucci decided that the negligence claim in Odhavji did disclose a reasonable cause of action. Moreover, we know from Imperial Tobacco that the pleadings must disclose a reasonable cause of action, not that a reasonable cause of action may emerge from facts that come forward in evidence at trial (ibid at para 24). It is difficult to reconcile the decision to strike out the claim in Imperial Tobacco with the decisions to allow it to proceed to trial in cases like Odhavji, supra note 10 and Taylor, supra note 84 . Odhavji creates a problematic precedent.

2008 SCC 27, [2008] 2 SCR 114 [Mustapha] (it is not foreseeable that a person of ordinary fortitude would suffer serious injury from seeing the flies in the bottle of drinking water he was about to open). RSO 1990, c P15. 
Justice Iacobucci explained that proximity required more than simple foreseeability. To establish proximity he relied heavily on the very general language of section 41(1)(b) of the Police Services Act which reads:

The duties of a chief of police include ... ensuring that members of the police force carry out their duties in accordance with this Act and the regulations and in a manner that reflects the needs of the community, and that discipline is maintained in the police force. ${ }^{105}$

Frankly, this statutory duty is no more on point than was the statutory duty to maintain a traffic patrol in Schacht. ${ }^{106}$ It speaks expressly of the needs of the community. It is therefore highly doubtful that the purpose of the section was intended to be for the chief to conduct investigations on behalf of grieving relatives, even though this could be an incidental effect. It even seems doubtful it was intended to provide information to the immediate victim, had the victim lived. This broadly worded provision extends well beyond matters relating to SIU investigations. If Odhavji was correctly decided, one can imagine numerous other duties of care being spawned by this statutory obligation.

Citing the Supreme Court's decision in Saskatchewan Wheat Pool, Justice Iacobucci also explained that a public authority's duty of care cannot be based on the statute alone. ${ }^{107}$ Accordingly, two other factors were said to support a finding of proximity: (1) a "close causal connection"; ${ }^{108}$ and (2) that "the public reasonably [expects] a chief of police to be mindful of the injuries that might arise as a consequence of police misconduct."109

The search for a close causal connection is a legitimate proximity inquiry. It might, on some very different facts, lead to a meaningful private party negligence analogy. ${ }^{110}$ The Court concluded that "the failure of the chief of police to ensure that the members of the force carry out their duties in accordance with the provisions of the Police Services Act leads directly to the police misconduct, which, in turn, leads directly to the complained of harm." "Frankly, it is difficult to see why a failure to act, that indirectly failed to benefit the plaintiffs, who were relatives of the actual victim of the shooting, which in turn caused them psychiatric damage, would be described as meaningfully close. ${ }^{112}$ The finding of foreseeability in this case was not in itself compelling. This particular close causal connection looks like foreseeability redux. Were the statute relevant at all, it would have sufficed to say the close family members of the deceased were in a proximate relationship with the chief.

No authority was cited in support of the public expectation approach. It may be a euphemism for general reliance. It may have been intended in Odhavji as a guideline for the

\footnotetext{
105 Ibid, s 41(1)(b).

106 Supra note 15.

107 Odhavji, supra note 10 at paras 31-32, citing Saskatchewan Wheat Pool, supra note 41.

108 Odhavji, ibid at para 56.

$109 \quad$ Ibid at para 57

110 The absence of a connection as close as this one was one basis for distinguishing the negligence claims brought against the Board (ibid at para 64). That the chief's connection was closer does not establish that it was meaningfully close.

111 Ibid at para 60

112 See supra notes $84-88$ and accompanying text.
} 
recognition of unique public authority duties. ${ }^{113}$ Certainly the public reasonably expects public authorities to perform their statutory duties. Reasonable informed members of the public may expect employees acting under statute to be disciplined, even dismissed, if they do not perform their public duties with due care. It is a different question entirely whether they reasonably expect the nation's police budgets to be increased to meet the prospects of unique public negligence suits in cases such as this. This expectation test really does not advance the matter, considering that courts commonly do have to determine whether the statutory duty is owed only to the public as a whole or to a particular member or group of members of the public. In those cases, as in this, the question is usually resolved by fiat. ${ }^{114}$ Beyond that, it is somewhat concerning to leave the case for disciplining public officials, often notorious whipping boys, to perceived public opinion. It would be better to have a satisfied public as the outcome of an otherwise principled decision to impose liability, than as a test for imposing liability in the first place.

If neither the close causal connection nor the public expectation factors adds anything of merit to the proximity analysis, the only other possibility that comes to mind is to look for existing analogous duties of care. It is surprising that the Court did not at least consider other recognized duties of affirmative action, albeit that it turns out that they offer little in support. There are two superficially helpful police decisions at the trial level, but neither carries much weight. ${ }^{115}$ There are duties owed to third parties based on the defendant's right to control the actual perpetrator of the direct harm. ${ }^{116}$ There is case law from the lower courts recognizing a doctor's duty to control a patient, ${ }^{117}$ and a parent's duty to control a child. ${ }^{118}$ These cases are not precisely on point because the duty is derived from independently recognized "special relationships" of control. It is questionable whether the chief really did have effective control over officers who were facing serious criminal charges and who were strongly represented by their labour union.

Closest to being an analogous duty is the seminal decision in Home Office. ${ }^{119}$ The House of Lords held that officers supervising adolescent training school detainees owed a duty to supervise them reasonably. In breach of that duty, the officers allowed the boys to escape and

The reasonable expectation factor was mentioned without elaboration in Childs, supra note 42 at para 40 , but not as unique to public authorities.

114 See e.g. Cooper, supra note 10 at para 44. See also Siebrasse, supra note 5 at 98.

115 See Jane Doe, supra note 84. The precedential value of this decision was questioned by Chief Justice McLachlin in Hill, supra note 4. Interestingly, the Supreme Court in Jane Doe relied on the decision in Schacht, supra note 15. See also Mooney v British Columbia (AG), 2001 BCSC 419, 2001 BCSC 419 (CanLII), aff'd 2004 BCCA 402, [2004] 10 WWR 286, leave to appeal to SCC refused, 30546 (3 March 2005). At trial a police officer was held to owe a duty of care to investigate and prevent crime. On appeal, the Court dismissed the action on the ground that the plaintiff failed to prove that the alleged breach of duty was the cause of the plaintiff's injuries which were suffered 47 days later. The issue of duty was given scant attention. See also Margaret Isabel Hall, "Duty, Causation, and Third-Party Perpetrators: The Bonnie Mooney Case" (2005) 50:3 McGill LJ 597. In the UK, see Michael, supra note 1; McBride, supra note 2 at 5-7 (the majority took a "Diceyan" as opposed to a policy approach to the issue. This idea is developed more fully in McBride \& Bagshaw, supra note 14).

116 See generally Hall, "Duty to Protect," supra note 42.

117 Wenden $v$ Trikha et al (1992), 124 AR 1 (QB), aff'd (1993), 135 AR 382 (CA), leave to appeal to SCC refused 23495 (2 September 1994). See also Douglas M Smith, "Wenden v. Trikha and Third Party Liability of Doctors and Hospitals: What's Been Happening to Tarasoff' (1995/96) 4:2 Health L Rev 12.

118 See Lelarge v Blakney (1978), 23 NBR (2d) 669 at para 12 (CA). See also Taylor v King, [1993] 8 WWR 92 (BCCA) at para 44.

119 Supra note 25 (the defendant Dorset may have also created the risk). See also Hill v Chief Constable of West Yorkshire (1988), [1989] 1 AC 53 at 62 (HL (Eng)) (to rely on a statute to create a private duty of care the plaintiff must establish: (1) the defendant's duty to control the perpetrator; and (2) the plaintiff's membership in a special class of foreseeable victims). 
do damage to property owned by third parties living in the vicinity. The House of Lords dismissed the Home Office's motion to strike out the claim. The argument in favour of a duty in Odhavji is that the statute created a duty on the part of the chief to supervise police officers, just as the statute in Home Office established a duty to supervise the detainees. In both cases the defendants breached that duty, and in both cases the breach allegedly allowed the subjects of the supervisory duty to injure the plaintiffs.

On the other hand, it is unlikely that the chief of police enjoyed the same degree of control over police officers potentially facing criminal charges as did the warders in Home Office. Second, the actual harm in Odhavji was for psychiatric damage. ${ }^{120}$ In the other cases the damage was physical damage; property damage in Home Office, and personal injury including rape and murder in the other cases. ${ }^{121}$ Psychiatric damage, or nervous shock as it was originally known, has always been governed by different and more restrictive rules of recovery than personal injury or property damage. Justice Iacobucci was rightly skeptical that the plaintiffs in Odhavji would be able to establish a legally recognized psychiatric injury. He ought to have been equally skeptical about foreseeability. As the Mustapha decision illustrates, foreseeability of psychiatric injury seems to be defined differently from foreseeability of physical harm. ${ }^{122}$ The history of the law governing nervous shock is dominated by psychiatric injury caused by an immediate "shock." The shock itself is typically associated with an accident causing personal injury or the prospect of personal injury to someone. The plaintiff usually must witness the accident or learn about it in the immediate aftermath of the accident. There is usually a directness requirement. ${ }^{123}$

In Odhavji, the plaintiffs were seeking damages for "mental distress, anger, depression and anxiety." 124 The claim was not based on witnessing the shooting itself, or learning about it in the immediate aftermath. The plaintiffs alleged that the continuing failure to ensure a proper SIU investigation of the death of their relative caused them psychiatric damage. Surely this is a "novel situation," not one that is analogous to an established category of liability. ${ }^{125}$ Perhaps a detailed consideration of the psychiatric damage element of the claim in Odhavji might have led the Supreme Court to expand the law of recovery for psychiatric damage in both private and public defendant cases. This seems unlikely, but possible. In the absence of such an enterprise, we are left with a unique duty of care based entirely on the statutory duty.

Is this a good decision? The chief of police was not covered by the Proceedings Against the Crown Act. ${ }^{126}$ The chief was an individual defendant who, as such, may have had an interest in personal autonomy that usually suffices to preclude recognition of affirmative obligations to benefit others. At the same time, this was a unique public duty based on a statute. It is hard to imagine a similar duty being imposed on a private employment

Supra note 10 at para 41

See supra note 115.

Supra note 103.

Rhodes v Canadian National Railway (1990), 75 DLR (4th) 248 (BCCA). See generally The Honourable Allen M Linden \& Bruce Feldthusen, Canadian Tort Law, 9th ed (Markham: LexisNexis, 2011) at ch 11.

Supra note 10 at para 40.

Cooper, supra note 10 at para 39.

See Proceedings Act, supra note 23. 
supervisor, especially for psychiatric damage. Do courts have the institutional expertise to evaluate discipline issues in the unionized environment of police services?

\section{E. A Duty on the Part of Government SAFety Inspectors TO Protect Workers From the CONSEQUENCES OF Criminal Conduct Perpetrated by Others}

The Fullowka case arose out of a bitter, violent labour dispute at a gold mine. ${ }^{127}$ The mine owners continued to operate the mine with replacement workers. There was a great deal of violence, including numerous explosions. Eventually one striker entered the mine and set up a trip wire to dynamite. The wire was tripped killing nine miners. Their estates and a rescuer brought an action against various parties including Pinkerton's, the security firm hired by the owners to protect the mine, and the territorial government.

Justice Cromwell writing for a unanimous Supreme Court concluded there was sufficient proximity between Pinkerton's, the private defendant, and the miners:

\footnotetext{
Pinkerton's must have shared the miners' expectation. It was there to protect property and people. The whole point of its presence was to help secure the site so that the mine could continue to operate. The miners who continued to work during the strike made up a well-defined and identifiable group. Pinkerton's surely ought to have expected that the very people it was there to protect would rely on it to exercise reasonable care in doing so. $^{128}$
}

This is a novel basis for proximity in private party negligence law. Pinkerton's was there to perform a contract with the mine owners. Unless one can found liability on a third party beneficiary to contract theory, the plaintiffs should have been restricted to suing the owners, who in turn could bring Pinkerton's into the suit. The miners were the incidental, not the intended, primary beneficiaries of the contract. There is no doubt the workers knew what Pinkerton's was hired to do and relied on them to do it properly. We rely on all sorts of people in a general way. But it should take more than a non-induced decision to rely on another to create a relationship of proximity. The defendant must do something to indicate it is assuming responsibility to the plaintiffs. ${ }^{129}$ In fact, the trial judge and the Court of Appeal both found that Pinkerton's did give assurances to the miners that the mine was safe. The entire duty issue could have been resolved by misrepresentation precedents, or at least by a very close analogy. There was no need for the Supreme Court to turn unilateral reliance into a sword unless this was thought necessary to prop up the suspect public duty that was next established.

Turning to the duty owed by the government, who gave no undertakings and made no representations, the Court relied on two points. First, there was the statutory language in section 42 of the Mining Safety Act, stating that a mining inspector shall "order the immediate cessation of work in ... a mine ... that the inspector considers unsafe"

Ibid at para 31 (the breadth of the proximity analysis was moot because the Court held that Pinkerton's did not breach the standard of care). 
combined with the broad parameters of the inspectors' obligation under section 43 "to give notice of any matter, thing or practice ... that, in the opinion of the inspector, is dangerous." 131

The government argued that these duties related to the prevention of accidents, not to the prevention of intentional criminal acts. As in the cases discussed previously, the best one can say is that the statute did not negate the possibility of a duty of care. As in Odhavji, the statutory language is broad enough to support many different obligations beyond the specific one at issue in the case.

Second, the Court engaged in a broader-based proximity analysis, as it should:

\begin{abstract}
In the case of the mining safety regulators and the miners, the closeness of the relationship is somewhere between that in Hill, on the one hand, and Cooper and Edwards on the other ... the relationship between the inspectors and the miners was considerably closer and more direct than the relationships in issue in Edwards or Cooper... The persons to whom mining inspectors are said to owe a duty — those working in the mine - is not only a much smaller but also a more clearly defined group than was the case in Cooper or Edwards.... [T] he mining inspectors had much more direct and personal dealings with the deceased miners than the Law Society or the Registrar had with the clients of the lawyer or mortgage broker in Edwards and Cooper.... Finally, the inspectors' statutory duties related directly to the conduct of the miners themselves. ${ }^{132}$
\end{abstract}

These points are all correct, but I question whether they are sufficient to ground a duty of care analogous to those found in private party negligence law. The best one can say is that they are analogous to the suspect duty imposed on Pinkerton's. ${ }^{133}$ My suspicion that Fullowka imposed a unique duty of care on the government is only heightened by the fact that the Court relied on the decision in Kamloops ${ }^{134}$ to support doing so. ${ }^{135}$

\title{
III. Conclusions
}

Except for acknowledging that the enabling legislation is relevant to the duty of care analysis, the majority in the Supreme Court of Canada has never acknowledged explicitly that it has crafted a unique public duty of care, let alone justified doing so.

However, the Supreme Court must have been aware that it was creating controversial and unique public duties. These points were frequently made in dissenting judgments, even though the majority never responded to them. ${ }^{136}$

$131 \quad$ Ibid, s 43(1).

132 Fullowka, supra note 19 at paras 41-45.

133 According to Hogg, Monahan \& Wright, supra note 6 at 3, although there is no Crown liability legislation in the Northwest Territories, there is an informal understanding that a private party analogy is required as it is (ought to be) according to the federal and provincial legislation.

134 Supra note 16.

135 Fullowka, supra note 19 at 46-47.

136 See e.g. the dissenting judgment of Justices Martland, Judson, and Pigeon in Schacht, supra note 15; the dissenting judgment of Justices Estey and McIntyre in Kamloops, supra note 16; the series of dissenting judgments by Justice Sopinka in the highway maintenance cases (Just, supra note 17; Swinamer, supra note 37; Brown, supra note 96). 
The Supreme Court has usually mentioned other decisions in support of what turns out to be a unique public duty. Sometimes this is just bootstrapping, the Court simply relies on other unique public duties that it has created, but not justified. In other cases, it turns out these references are not meaningfully analogous to the case in which they were raised.

A statutory public duty is different from a statutory tort duty. The Supreme Court has held that a statutory duty of care may not be implied from the statute. The legislature must create such a duty explicitly. ${ }^{137}$ The Supreme Court itself has held that a statutory public duty alone cannot support a common law duty of care. ${ }^{138}$ Yet it transpires that the sole justification for the new public tort duties has been the statutory public duty.

Historically the government enjoyed sovereign immunity from tort liability. Liability in tort depends on whether the government has agreed to be held liable in tort for the act or omission in question. Such consent is expressed in the relevant federal and provincial Crown liability legislation. The Crown has only consented to be liable if the act or omission would be tortious if done by a private party. It has not consented to unique Crown liability. The Supreme Court has either ignored or effectively eviscerated this legislation.

Most unique public duties emerged in the 1970s and 1980s, which was an expansionary era in negligence law. ${ }^{139}$ It is tempting to assume that these unique public duties will either disappear or be overruled. However, the opposite has happened. The Supreme Court has continued to promote these decisions, ${ }^{140}$ and to rely on them to forge new unique duties of care in the twenty-first century. ${ }^{141}$

An open discussion about whether, and if so under what circumstances, the Supreme Court ought to recognize unique public duties of care is long overdue.

Saskatchewan Wheat Pool, supra note 41.

Odhavji, supra note 10.

Indeed, many people believe that Lord Wilberforce's prima facie duty of care in Anns was based on foreseeability alone and that it extended to cover all allegations of negligence including government liability and including omissions. See e.g. Klar, "Judicial Activism," supra note 8 at 220 discussing Anns, supra note 3 .

The duty on municipalities who undertake home inspection programs, and the duties on public authorities who undertake highway maintenance programs were both expressly approved as recognized duties of care in Cooper, supra note 10 at para 36.

The home inspection duty from Kamloops, supra note 16 was relied upon to create another unique duty of care in Fullowka, supra note 19 at paras $46-47$. 
This page is blank - do not strip it in 